\title{
Clinical Trial Regulatory Filenote
}

National Cancer Institute

\section{Source}

National Cancer Institute. Clinical Trial Regulatory Filenote. NCI Thesaurus. Code

C115548.

A notation that describes any regulatory decisions, and/or clarification of any information in a clinical trial. 